\title{
Environmentally friendly paint and varnish additives based on isobutyrate aldehyde condensation products
}

\author{
Joanna Guziałowska-Tic ${ }^{1, *}$ and Wilhelm Jan Tic ${ }^{1}$ \\ ${ }^{1}$ Opole University of Technology, Department of Environmental Engineering, Mikołajczyka 5 Street, 45-271 Opole, Poland
}

\begin{abstract}
The demand for exploitation of new plasticizers and coalescents to be used for production of water dispersion adhesives based on poli(vinyl acetate), turned to be recently of particular significance because the use of all kind of toxic phthalates was banned and certain restrictions were made to use glycol derivatives classified as volatile organic compounds. An alternative for toxic plasticizers used for production of adhesives is hydroxyester (HE-1) obtained from isobutanal during the process of aldol condensation under subsequent Cannizaro and Tischenko reactions.

The paper presents selected results of ecotoxicological tests on the environmental impact of hydroxyester HE-1. It was found that the substance is biodegradable and has no negative impact on algae growth rate, however it may inhibit algae biomass growth. The results of Daphnia immobilization test shows that the substance is safe for the aquatic environment. Whereas, at higher concentrations, hydroxyester HE-1 may exhibit acute toxicity to rainbow trout.
\end{abstract}

\section{Introduction}

The solvents are mainly applied for production of protective coatings. Their large chemical variety includes liquid hydrocarbons and organochlorines, which due to their physicochemical properties are a significant burden to the natural environment [1]. Therefore, they are being consequently replaced with more environmentally friendly new-generation products.

An important legislation in this field is the European Directive 2004/42/EC, so-called "Decopaint Directive", which entered into force on 1 January 2007 [2]. It concerns emission reduction of solvents from decopaints and automotive lacquers classified as volatile organic compounds (VOC), which were previously not covered by the restrictions of the Directive no. 1999/13/EC on reduction of solvent emission [3].

According to the 2004/42/EC, a volatile organic compounds is every substance of onset boiling point at temperature of $250{ }^{\circ} \mathrm{C}$ or lower measured under pressure of $101.3 \mathrm{kPa}$.

Environmental hazards related to the VOC result from the fact that in the stratosphere they interact with stratospheric ozone leading to the depletion of ozone layer, which serves as a natural UV filter. While in the troposphere, at increased temperature and exposed to solar radiation, VOCs react with nitrogen oxides $\left(\mathrm{NO}_{\mathrm{x}}\right)$ producing tropospheric ozone, which is classified as a greenhouse gas and is one of smog components. Reaction rate, wind and possibility of delayed reaction due to the insufficient amount of sun light, means that ozone and generated smog can form with a few days delay, hundreds of kilometres from the source of VOC emission [4]. According to the recommendation of the World Health Organisation, the average eight-hour standard for ozone concentration is $120 \mu \mathrm{g} / \mathrm{m}^{3}$, while in Europe there are constantly reported concentrations exceeding this value. In order to reduce the quantity of generated tropospheric ozone, regulations were prepared aiming to reduce VOC emissions from various sources, including solvent-containing products.

The recipes for paints and varnishes commonly include plasticizers that are harmful to aquatic environment, persistent, bioaccumulative, toxic and classified as VOC $[5,6]$. The literature describes many examples of environmentally friendly plasticizers that can serve as an alternative for toxic ones [7-11]. The available literature focuses on the plasticization properties of these additive, however, there is not much data on their physicochemical, toxicological and ecotoxicological properties [10]. Table 1 presents selected alternative plasticizer with boiling temperature above $250^{\circ} \mathrm{C}$, i.e. not classified as VOC. These plasticizers are usually used as PVC additives, but also for other polymers. These materials can be also used as additives for lubricating oils and vinyl-acrylic dispersions [12].

Corresponding author: j.guzialowska@po.opole.pl 


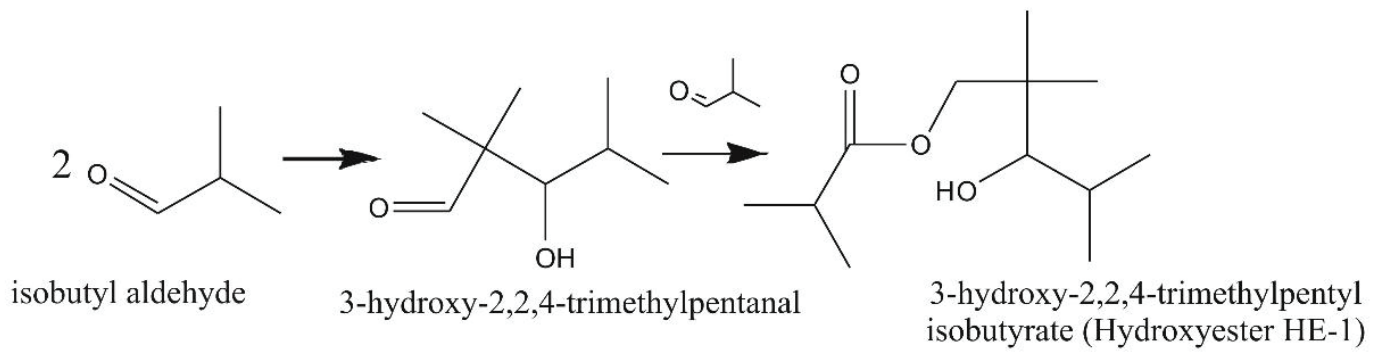

Fig. 1. General scheme of isubutanal condensation towards obtaining Hydroxyester HE1.

An alternative for withdrawn from use and limited plasticizers and coalescents for paints and varnishes is hydroxyester HE-1 obtained in a sequence of chemical reactions, where isobutyrate aldehyde is a main feed in the aldol condensation with subsequent Cannizzaro-Tishchenko reaction as shown in Fig. 1. Hydroxyester (HE-1) constitutes a mixture of two isomeric products, it is 3-hydroxy2,2,4-trimethylpropyl isobutyrate and 3-hydroxy2,2-dimethyl-1-(1-methylo)propyl isobutyrate that are in the equilibrium.

Hydroxyester HE-1 is a hydrophobic organic solvent, which is mainly used as a coalescent in formulations of water borne facade paints. The product has boiling point of $255^{\circ} \mathrm{C}$, which places it outside the VOC classification [13-15].

\section{Material and methods}

Due to the fact that it is planned to launch production of hydroxyester HE-1 in volume of 100 $\mathrm{Mg}$ per year, it is required to evaluate toxicological and ecotoxicological properties of the product [16]. The list of all ecotoxicological tests conducted for hydoxyester HE-1 is as fallows:

- Pseudokirchneriella subcapitata, growth inhibition test according to OECD guideline 201 [17],

- Daphnia magna, acute immobilization test according to OECD guideline 202 [18],

- Rainbow trout, acute toxicity test according to OECD guideline 203 [19],

- Earthworm, acute toxicity test according to OECD guideline 207 [20],

- Active sludge, respiration inhibition test according to OECD guideline 209 [21],

- Soil microorganisms: nitrogen transformation test according to OECD guideline 216 [22],

- Soil microorganisms: carbon transformation test according to OECD guideline 217 [23],

- Ready biodegradability according to OECD guideline 301 [24].

The test required to assess environmental risks were performed in accordance with good laboratory practice at the Institute of Industrial Organic Chemistry (IPO) in Pszczyna.

The paper presents results of four selected ecotoxicological tests including biodegradability, acute toxicity test for rainbow trout, algae growth inhibition test and acute immobilization test for Daphnia. The description of how the test was conducted can be found below.

\subsection{Pseudokirchnereilla subcapitata, growth inhibition test according to the OECD Guideline No. 201}

The test aimed to determine concentrations of the test material (hydroxyester HE-1) causing 50\% inhibition of average specific growth rate and biomass growth for algae Pseudokirchneriella subcapitata $\mathrm{E}_{\mathrm{r}} \mathrm{C}_{50}$ and $\mathrm{E}_{\mathrm{y}} \mathrm{C}_{50}$, respectively, after 72 $\mathrm{h}$ exposure), as well as determination of the lowest concentration (LOEC) of the test material causing growth inhibition compared to the control and the highest material concentration causing no effect compared to the control (NOEC).

At the beginning of the experiment, algae density was $1 \times 10^{4}$ cells $/ \mathrm{cm}^{3}$. The test used the following concentrations of the test material: 5,10 , 20, 40 and $80 \mathrm{mg} / \mathrm{dm}^{3}$ and the control $(0.0$ $\left.\mathrm{mg} / \mathrm{dm}^{3}\right)$. Algae density was determined by means of spectrophotometry measuring absorbance of algae suspension at wavelength $\lambda 670 \mathrm{~nm}$ after 24 , 48 and 72 hours of exposure. The measured absorbance values were converted to cell density using the regression curve (nomogram). The nomogram was prepared by diluting $72 \mathrm{~h}$ algae culture and obtaining series of samples. For each sample, cell density was counted in Bürker chamber by microscopy and the absorbance was measured. Cell density was calculated from the linear regression equation $\mathrm{y}=0.6003 \mathrm{x}-0.0003$ with correlation coefficient $\mathrm{R}^{2}=0.9953$.

For calculation of algae growth rate and algae biomass growth, the following equations (1) and (2) were used:

Growth rate $(0-72 \mathrm{~h})=$

$\frac{[\ln (\text { cell density at } 72 \mathrm{~h})]-[\ln (\text { cell density at } 0 \mathrm{~h})]}{3 \text { days }}$

Biomass growth $\left[10^{6}\right.$ cells in $\left.\mathrm{cm}^{3}\right]=$ (cell density at $72 h)-($ cell density at $0 h)$ 


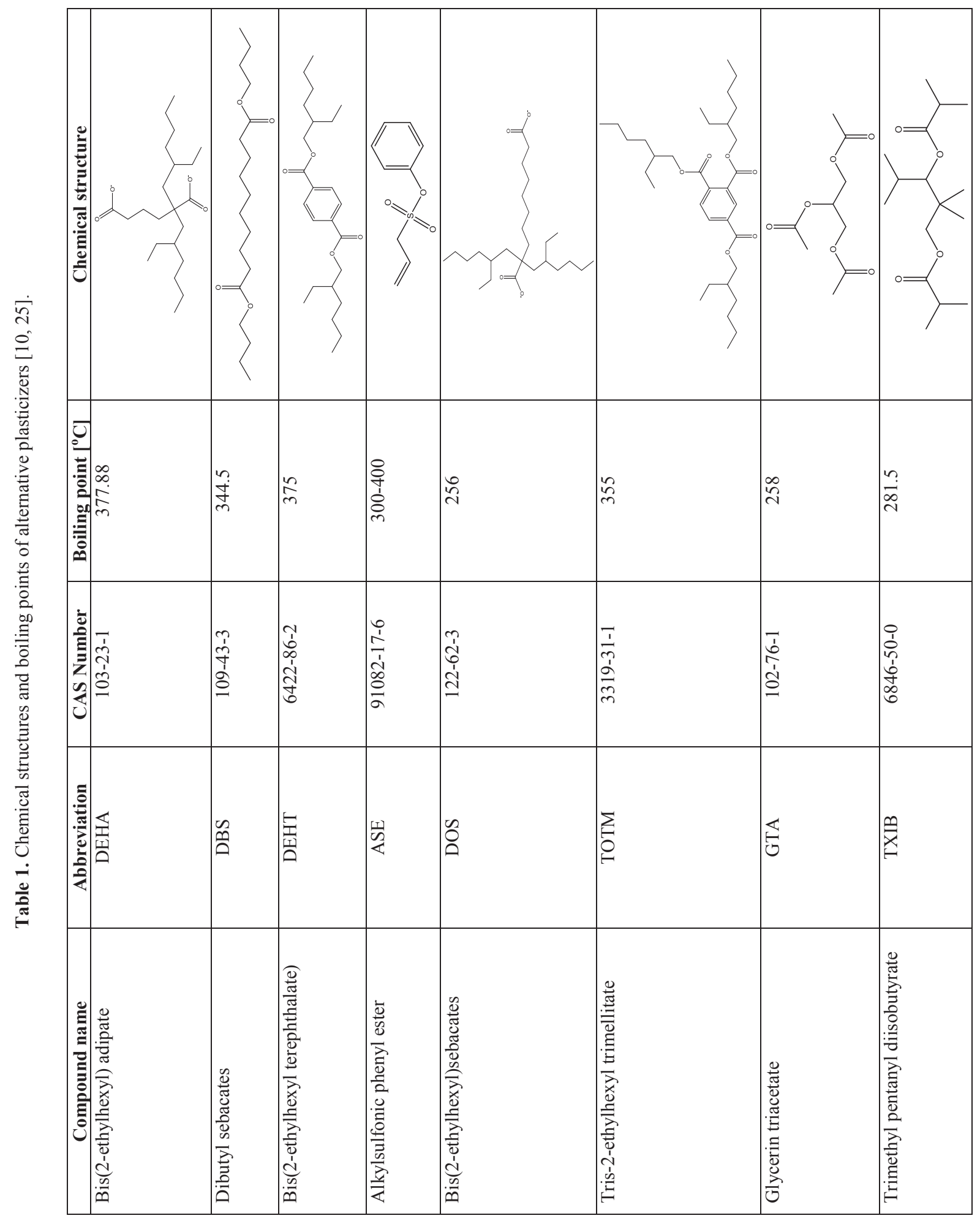


The calculations and statistical analysis were performed using commercial software ToxRat Professional.

According to the Regulation of the Minister of Health on criteria and classification methods concerning chemical substances and their mixtures, the chemical substance has no negative impact on algae growth, if values $\mathrm{E}_{\mathrm{r}} \mathrm{C}_{50}$ and $\mathrm{E}_{\mathrm{y}} \mathrm{C}_{50}$ after $72 \mathrm{~h}$ are higher than $100 \mathrm{mg} / \mathrm{dm}^{3}$ [26].

\subsection{Daphnia magna, acute immobilization test according to the OECD guideline 202}

The aim of test was to determine toxic effect of hydroxyester HE-1 on Daphnia and determination of average concentrations causing 0, 50 and 100\% Daphnia immobilization (determination of $\mathrm{EC}_{50}$, $\mathrm{EC}_{0}$ and $\mathrm{EC}_{100}$ in $\mathrm{mg} / \mathrm{dm}^{3}$ ) after $24 \mathrm{~h}$ and $48 \mathrm{~h}$ of exposure.

The main experiment used limiting concentration of $100 \mathrm{mg} / \mathrm{dm}^{3}$ obtained by dissolving $50 \mathrm{mg}$ of tested material in $500 \mathrm{~cm}^{3}$ of water in measuring flask. The experiment included four repetitions with 5 tests organisms in each. Daphnia sensitivity was also checked in the reference test for reference substance, i.e. potassium dichromate $\left(\mathrm{K}_{2} \mathrm{Cr}_{2} \mathrm{O}_{7}\right)$.

According to the Regulation of the Minister of Health on criteria and classification methods concerning chemical substances and their mixtures, the chemical substance is safe to the aquatic environment (Daphnia), if value $\mathrm{EC}_{50}$ after $48 \mathrm{~h}$ is higher than $100 \mathrm{mg} / \mathrm{dm}^{3}$ [26].

\subsection{Rainbow trout, acute toxicity test according to the OECD guideline 203}

The aim of the test was to determine acute toxicity for rainbow trout (Oncorhynchus mykiss Walb.) and value of $\mathrm{LC}_{50}$ (concentration causing $50 \%$ lethality in tested population) after $24,48,72$ and $96 \mathrm{~h}$, as well as determination of $\mathrm{LC}_{0}$ (highest tested concentration causing no lethality by the end of the test) and $\mathrm{LC}_{100}$ (the lowest tested concentration causing $100 \%$ lethality after exposure time).

Rainbow trout, acute toxicity test for hydroxyester HE-1 was conducted in a static system. The fish was exposed to test material at concentrations: $5.6 ; 10.0 ; 18.0 ; 32.0$ and 56.0 $\mathrm{mg} / \mathrm{dm}^{3}$ plus the control $\left(0.0 \mathrm{mg} / \mathrm{dm}^{3}\right)$. The experiment was conducted in $35 \mathrm{dm}^{3}$ glass aquaria on four months old fish. Each aquarium contained 7 fish, while observations of lethality and intoxication symptoms were conducted after 3, 6, 24, 48, 72 and 96 hours of exposure. Trout sensitivity was also concerning chemical substances and their mixtures, the chemical substance is safe to the aquatic environment (trout), if value $\mathrm{LC}_{50}$ after $96 \mathrm{~h}$ is higher than $100 \mathrm{mg} / \mathrm{dm}^{3}$ [26].

\subsection{Ready biodegradability according to the OECD guideline 301}

The aim of test was to determine by laboratory means, ready biodegradability of hydroxyester HE1 in the aquatic environment after 28 days of experiment. As inoculum in the test, active sludge filtrate from biological wastewater treatment plant was used. The measuring system consisted of 0.3 $\mathrm{dm}^{3}$ bottles for BOD determination filled with mixture composed of specific quantities of water, culture medium, active sludge and reference substance solutions and tested materials selected in the accordance with [24]. Sodium acetate was used as a reference substance at concentration of 5 $\mathrm{mg} / \mathrm{dm}^{3}$, while the test material had concentration of $2 \mathrm{mg} / \mathrm{dm}^{3}$.

Oxygen concentration was measured using oxygen probe placed directly in the BOD bottles. Two samples were taken from each series for oxygen concentration analysis in one week intervals during the 28 days of incubation.

The obtained results were used to calculate biochemical oxygen demand (BOD), i.e. amount of oxygen consumed by microorganisms for metabolism of chemical.

While the \%biodegradation of test material and reference material was calculated using the following equation:

$$
\begin{array}{r}
\% \text { biodegradation }= \\
\frac{B O D\left(\mathrm{mg} \mathrm{O}_{2} / \mathrm{mg} \text { of test material }\right)}{\operatorname{TOD}\left(\mathrm{mg} \mathrm{O}_{2} / \mathrm{mg} \text { of test material }\right)} \times 100
\end{array}
$$

Theoretical oxygen demand (TOD) was calculated based on the molecular formula and is a total amount of oxygen required to oxidize the chemical compound.

The theoretical molecular formula of hydroxyester HE- $1\left(\mathrm{C}_{12} \mathrm{H}_{24} \mathrm{O}_{3}\right)$ was used to calculate TOD, which was $2.44 \mathrm{mgO}_{2} / \mathrm{mg}$, while for sodium acetate $\left(\mathrm{C}_{2} \mathrm{H}_{3} \mathrm{NaO}_{2}\right)-0.78 \mathrm{mgO}_{2} / \mathrm{mg}$.

According to the Regulation of the Minister of Health on criteria and classification methods concerning chemical substances and their mixtures [26], the chemical substance is considered readily biodegradable, if after 28 day biodegradability test, a $60 \%$ biodegradation is achieved in tests based on oxygen loss [27].

\section{Results and discussion}

\subsection{Pseudokirchnereilla subcapitata, growth inhibition test according to the OECD Guideline No. 201}

Fig. 2 presents effect of the test material on Pseudokirchneriella subcapitata growth rate and biomass growth. 


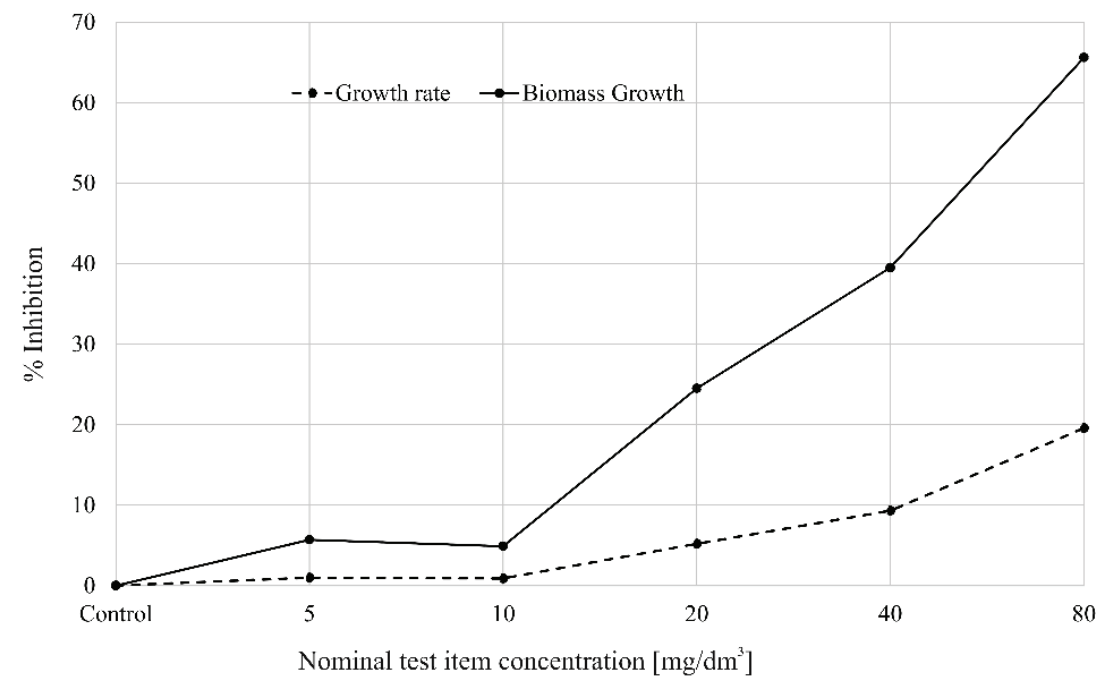

Fig. 2. Inhibition of biomass growth and growth for various concentrations of hydroxyester HE-1 in comparison to the control after $72 \mathrm{~h}$.

Fig. 2 leads to the conclusion that hydroxyester HE-1 has greater effect on biomass growth than on algae growth rate. The greatest effect on biomass growth was observed for test material concentration above $10 \mathrm{mg} / \mathrm{dm}^{3}$, while for the growth rate it was for concentration exceeding $40 \mathrm{mg} / \mathrm{dm}^{3}$.

$\mathrm{ECx}$ values were determined based on nominal concentrations of the test material for biomass growth and growth rate (Table 2).

The concentration causing $50 \%$ growth rate inhibition in Pseudokirchneriella subcapitata $\left(\mathrm{E}_{\mathrm{r}} \mathrm{C}_{50} / 72 \mathrm{~h}\right)$ was above $80 \mathrm{mg} / \mathrm{dm}^{3}$, i.e. for the highest used in the experiment. Whereas $\mathrm{E}_{\mathrm{r}} \mathrm{C} 2_{0} / 72 \mathrm{~h}$ was also $>80 \mathrm{mg} / \mathrm{dm}^{3}$, and $\mathrm{E}_{\mathrm{r}} \mathrm{C}_{10} / 72 \mathrm{~h}$ was 36.46 $\mathrm{mg} / \mathrm{dm}^{3}$. The obtained $\mathrm{E}_{\mathrm{r}} \mathrm{C}_{50}$ was above $80 \mathrm{mg} / \mathrm{dm}^{3}$, which means that hydroxyester HE-1 has no negative impact on the aquatic environment. Whereas average concentration causing 50\% algae biomass growth $\mathrm{E}_{\mathrm{y}} \mathrm{C}_{50} / 72 \mathrm{~h}$ was $48.10 \mathrm{mg} / \mathrm{dm}^{3}$, $\mathrm{E}_{\mathrm{y}} \mathrm{C}_{20} / 72 \mathrm{~h}-16.47 \mathrm{mg} / \mathrm{dm}^{3}$, while $\mathrm{E}_{\mathrm{y}} \mathrm{C}_{10} / 72 \mathrm{~h}$ was $9.37 \mathrm{mg} / \mathrm{dm}^{3}$. The obtained value of $\mathrm{E}_{\mathrm{y}} \mathrm{C}_{50}$ is greater than $10 \mathrm{mg} / \mathrm{dm}^{3}$, but lower than $100 \mathrm{mg} / \mathrm{dm}^{3}$. According to the Regulation of the Minister of Health of on criteria and classification methods concerning chemical substances and their mixtures, this means that hydroxyester HE-1 at higher concentrations may affect algae biomass growth [26].

LOEC and NOEC after 24, 48, $72 \mathrm{~h}$ were calculated next for nominal concentration of the tested preparation. LOEC for biomass growth and average specific growth rate was $20 \mathrm{mg} / \mathrm{dm}^{3}$, while NOEC for biomass growth and average specific growth rate was $10 \mathrm{mg} / \mathrm{dm}^{3}$.

3.2 Daphnia magna, acute immobilization test according to the OECD guideline 202
Total lethality for the tested material (hydroxyester HE-1) at concentration of 100 $\mathrm{mg} / \mathrm{dm}^{3}$ after 24 and 48 hours of exposure was $0 \%$. For comparison, total lethality for the reference material $\left(\mathrm{K}_{2} \mathrm{Cr}_{2} \mathrm{O}_{7}\right)$ at concentration of $3.2 \mathrm{mg} / \mathrm{dm}^{3}$ after 24 hours of exposure was $60 \%$, and after $48 \mathrm{~h}$ $-100 \%$.

The results of Daphnia acute immobilization test for the tested material are presented in table 3 . Average concentration causing 50\% Daphnia immobilization $\left(\mathrm{EC}_{50}\right)$ after $24 \mathrm{~h}$ is above 100 $\mathrm{mg} / \mathrm{dm}^{3} . \mathrm{EC}_{0}$ after $24 \mathrm{~h}$ is equal to $100 \mathrm{mg} / \mathrm{dm}^{3}$ or greater, while $\mathrm{EC}_{100}$ after $24 \mathrm{~h}$ is above 100 $\mathrm{mg} / \mathrm{dm}^{3}$.

Average concentration causing 50\% Daphnia immobilization $\left(\mathrm{EC}_{50}\right)$ after $48 \mathrm{~h}$ is above 100 $\mathrm{mg} / \mathrm{dm}^{3} . \mathrm{EC}_{0}$ after $48 \mathrm{~h}$ is equal to $100 \mathrm{mg} / \mathrm{dm}^{3}$ or greater, while $\mathrm{EC}_{100}$ after $48 \mathrm{~h}$ is above $100 \mathrm{mg} / \mathrm{dm}^{3}$ (Table 3).

Table 2. $\mathrm{E}_{\mathrm{y}} \mathrm{C}_{\mathrm{x}}$ and $\mathrm{E}_{\mathrm{r}} \mathrm{C}_{\mathrm{x}}$ values calculated according to the method based on the biomass growth analysis and the average specific growth rate for hydroxyester HE-1 concentrations, where N/A - not calculated due to the mathematical resons.

\begin{tabular}{|l|c|c|c|}
\hline \multirow{2}{*}{\begin{tabular}{|}
$\mathbf{E}_{\mathbf{r}} \mathbf{C}_{\mathbf{x}}$ \\
{$\left[\mathbf{m g} / \mathbf{d m}^{\mathbf{3}}\right]$}
\end{tabular}} & \multicolumn{3}{|c|}{ Exposure time [h] } \\
\cline { 2 - 4 } & $\mathbf{2 4}$ & $\mathbf{4 8}$ & $\mathbf{7 2}$ \\
\hline $\mathbf{E}_{\mathbf{r}} \mathbf{C}_{\mathbf{1 0}}$ & N/A & 25.30 & 36.46 \\
\hline $\mathbf{E}_{\mathbf{r}} \mathbf{C}_{\mathbf{2 0}}$ & $<5.00$ & 74.84 & $>80.00$ \\
\hline $\mathbf{E}_{\mathbf{r}} \mathbf{C}_{\mathbf{5 0}}$ & $<5.00$ & $>80.00$ & $>80.00$ \\
\hline $\mathbf{E}_{\mathbf{y}} \mathbf{C}_{\mathbf{x}}$ & \multicolumn{3}{|c|}{ Exposure time [h] } \\
\cline { 2 - 4 } & $\mathbf{2 4}$ & $\mathbf{4 8}$ & $\mathbf{7 2}$ \\
\hline $\mathbf{E}_{\mathbf{y}} \mathbf{C}_{\mathbf{1 0}}$ & $<5.00$ & 6.33 & 9.37 \\
\hline $\mathbf{E}_{\mathbf{y}} \mathbf{C}_{\mathbf{2 0}}$ & $<5.00$ & 13.67 & 16.47 \\
\hline $\mathbf{E}_{\mathbf{y}} \mathbf{C}_{\mathbf{5 0}}$ & 10.46 & 59.09 & 48.10 \\
\hline
\end{tabular}


Table 3. $\mathrm{EC}_{\mathrm{x}}$ values for hydroxyester HE-1 and for the reference substance $-\mathrm{K}_{2} \mathrm{Cr}_{2} \mathrm{O}_{7}$

\begin{tabular}{|c|c|c|c|c|c|c|}
\hline \multirow{2}{*}{$\begin{array}{c}\text { Exposure } \\
\text { time }\end{array}$} & \multicolumn{6}{|c|}{$\mathbf{E C}_{\mathbf{x}}\left[\mathbf{m g} / \mathbf{d m}^{\mathbf{3}}\right]$} \\
\cline { 2 - 7 } & $\mathbf{H E - 1}$ & $\mathbf{K}_{\mathbf{2}} \mathbf{C r}_{\mathbf{2}} \mathbf{O}_{\mathbf{7}}$ & $\mathbf{H E}-\mathbf{1}$ & $\mathbf{K}_{\mathbf{2}} \mathbf{C r}_{\mathbf{2}} \mathbf{O}_{\mathbf{7}}$ & $\mathbf{H E}-\mathbf{1}$ & $\mathbf{K}_{\mathbf{2}} \mathbf{C r}_{\mathbf{2}} \mathbf{O}_{\mathbf{7}}$ \\
\cline { 2 - 7 } & $>100$ & 2.58 & $\geq 100$ & 1.0 & $>100$ & $>3.2$ \\
\hline $24 \mathrm{~h}$ & $>100$ & 1.26 & $\geq 100$ & 0.56 & $>100$ & 3.2 \\
\hline $48 \mathrm{~h}$ & \multicolumn{3}{|c|}{} \\
\hline
\end{tabular}

As the value of $\mathrm{EC}_{50}$ after 48 hours of exposure is greater than $100 \mathrm{mg} / \mathrm{dm}^{3}$, according to [26], hydroxyester HE-1 has no negative environmental impact (Daphnia). In turn, for the reference material, $\mathrm{EC}_{50} / 48 \mathrm{~h}$ was $1.26 \mathrm{mg} / \mathrm{dm}^{3}, \mathrm{EC}_{0}-0.56$ $\mathrm{mg} / \mathrm{dm}^{3}$, and $\mathrm{EC}_{100}-3.2 \mathrm{mg} / \mathrm{dm}^{3}$ (Table 3).

\subsection{Rainbow trout, acute toxicity test according to the OECD guideline 203}

Hydroxyester HE-1 toxicity to trout was assessed based on the observation of lethality and intoxication symptoms. After $3 \mathrm{~h}$ from the start of the experiment, intoxication symptoms were observed. For concentration of $18 \mathrm{mg} / \mathrm{dm}^{3} 1$ fish showed loss of balance, 2 fish - unusual swimming, while the increased pigmentation was observed in all the fish. While at concentration of $32 \mathrm{mg} / \mathrm{dm}^{3}$, all the fish exhibited loss of balance, unusual swimming and increased pigmentation.

At the highest used concentration $\left(56 \mathrm{mg} / \mathrm{dm}^{3}\right)$, $100 \%$ lethality was observed after 30 minutes from the start of the experiment. At other concentrations, no lethality was observed during the whole experiment. For comparison, 100\% lethality after 48 hours was observed the reference substance (potassium dichromate) at concentration of 32 $\mathrm{mg} / \mathrm{dm}^{3}$. Then, hydroxyester HE-1 toxicity to trout was assessed based on the observation of lethality and intoxication symptoms.

It was shown that $\mathrm{LC}_{0}$ and $\mathrm{LC}_{100}$ after $96 \mathrm{~h}$ of exposure were $32 \mathrm{mg} / \mathrm{dm}^{3}$ and $56 \mathrm{mg} / \mathrm{dm}^{3}$, respectively. Whereas, the average concentration causing $50 \%$ fish lethality $\left(\mathrm{LC}_{50}\right)$ after $96 \mathrm{~h}$ was above $41 \mathrm{mg} / \mathrm{dm}^{3}$. This means that according to [26], hydroxyester HE-1 at high concentrations may have harmful impact on aquatic organisms and may cause long-term adverse effects in the aquatic environment.

\subsection{Ready biodegradability according to the OECD guideline 301}

Average oxygen consumption and biochemical oxygen demand (BOD) on $0,7,14,21$ and 28 day of analysis for the test material and for the reference material are presented below.

For the tested material, BOD varied from $0.19 \mathrm{mg}$ $\mathrm{O}_{2} / \mathrm{dm}^{3}$ on the seventh day of the experiment, up to $1.51 \mathrm{mg} \mathrm{O} / \mathrm{dm}^{3}$ on the last day of the experiment. Whereas, for the reference material (sodium acetate), BOD varied from $0.57 \mathrm{mg} \mathrm{O}_{2} / \mathrm{dm}^{3}$ on the first day of the experiment, up to $0.72 \mathrm{mg} \mathrm{O}_{2} / \mathrm{dm}^{3}$ on the last day of the experiment.

The calculated values of TOD and BOD were used in the equation (3) to determine biodegradability for hydroxyester HE-1 and for the reference material, i.e. sodium acetate (Fig. 3).

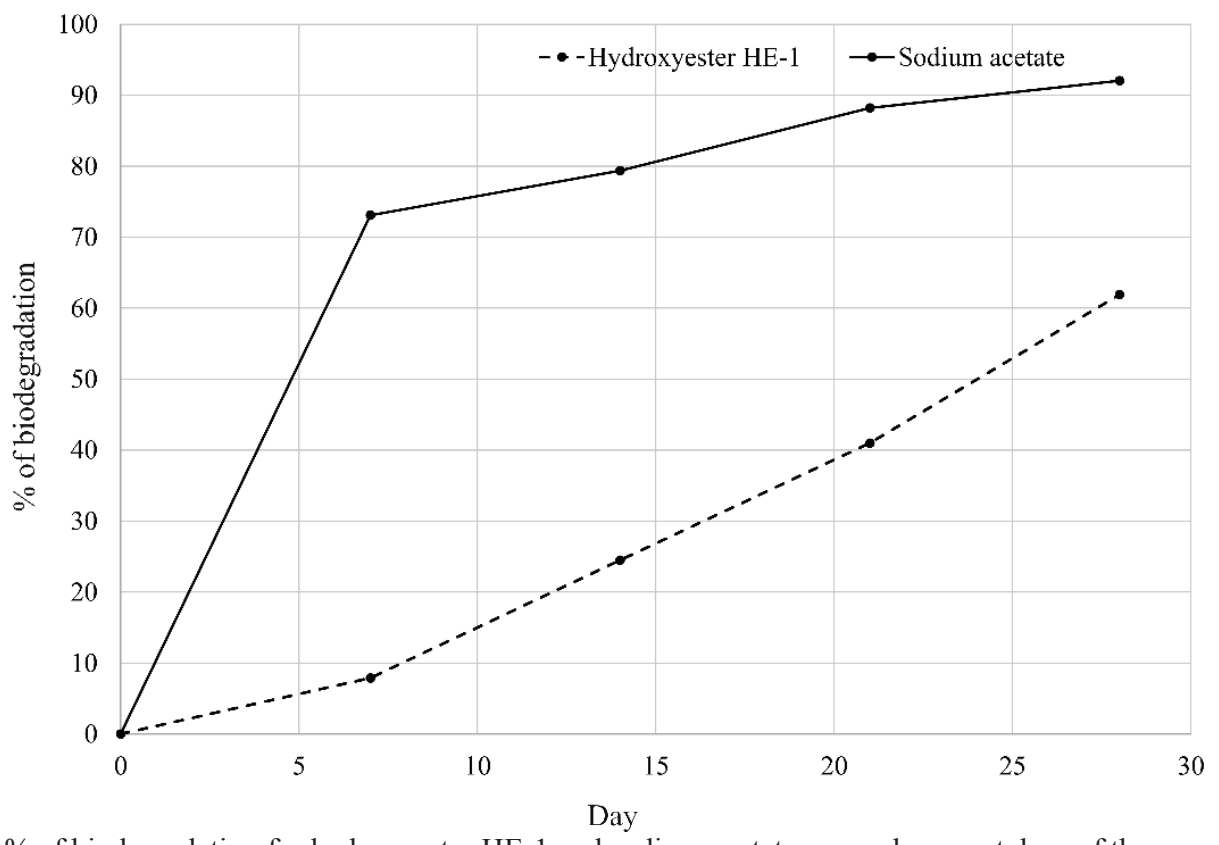

Fig. 3. \% of biodegradation for hydroxyester HE-1 and sodium acetate on a subsequent days of the experiment. 
Table 4. Comparison of selected ecotoxicological properties for hydroxyester HE-1 and other plasticizers [25], where: ${ }^{*}$ - instead of toxicity to algae test acc. to the OECD guideline no. 211, algae growth inhibition test was performed acc. to the OECD guideline no. 201.

\begin{tabular}{|l|l|l|l|l|}
\hline $\begin{array}{c}\text { Chemical } \\
\text { compound }\end{array}$ & $\begin{array}{l}\text { Toxicity to fish } \\
\text { LC50/96h }\end{array}$ & $\begin{array}{l}\text { Toxicity to Daphnia } \\
\text { magna; EC50/48h }\end{array}$ & $\begin{array}{l}\text { Toxicity to aquatic algae; } \\
\text { EC50/72h }\end{array}$ & $\begin{array}{l}\text { Biodegradability } \\
\text { BOD5 }\end{array}$ \\
\hline DEHA & $>100 \mathrm{mg} / \mathrm{dm}^{3}$ & $0.66 \mathrm{mg} / \mathrm{dm}^{3}$ & $>500 \mathrm{mg} / \mathrm{dm}^{3}$ & $94 \%$ \\
\hline DBS & $>10,000 \mathrm{mg} / \mathrm{dm}^{3}$ & $>1000 \mathrm{mg} / \mathrm{dm}^{3}$ & $>1000 \mathrm{mg} / \mathrm{dm}^{3}$ & $89.6 \%$ \\
\hline DOS & $>1000 \mathrm{mg} / \mathrm{dm}^{3}$ & $>1000 \mathrm{mg} / \mathrm{dm}^{3}$ & $>1000 \mathrm{mg} / \mathrm{dm}^{3}$ & $65 \%$ \\
\hline DEHT & $>984 \mathrm{mg} / \mathrm{dm}^{3}$ & $>984 \mathrm{mg} / \mathrm{dm}^{3}$ & $>0.86 \mathrm{mg} / \mathrm{dm}^{3}$ & $73.05 \%$ \\
\hline TOTM & $>100 \mathrm{mg} / \mathrm{dm}^{3}$ & $>180 \mathrm{mg} / \mathrm{dm}^{3}$ & $>100 \mathrm{mg} / \mathrm{dm}^{3}$ & biodegradable \\
\hline ASE & no data & no data & no data & $24 \%$ \\
\hline GTA & no data & $770 \mathrm{mg} / \mathrm{dm}^{3}$ & $>940 \mathrm{mg} / \mathrm{dm}^{3}$ & $59.4 \%$ \\
\hline TXIB & $>1.55 \mathrm{mg} / \mathrm{dm}^{3}$ & $>1.55 \mathrm{mg} / \mathrm{dm}^{3}$ & $>7.49 \mathrm{mg} / \mathrm{dm}^{3}$ & $32 \%$ \\
\hline HE-1 & $41 \mathrm{mg} / \mathrm{dm}^{3}$ & $>100 \mathrm{mg} / \mathrm{dm}^{3}$ & $\begin{array}{l}\mathrm{E}_{\mathrm{r}} \mathrm{C}_{50}>80 \mathrm{mg} / \mathrm{dm}^{3} \\
\mathrm{E}_{\mathrm{r}} \mathrm{C}_{50}=48.10 \mathrm{mg} / \mathrm{dm}^{3}\end{array}$ & $61.9 \%$ \\
\hline
\end{tabular}

\subsection{Comparison of ecotoxicological properties for hydroxyester HE-1 and alternative plasticizers}

Table 4 presents comparison of ecotoxicological properties determined for hydroxyester HE-1 and 8 state-of-the-art plasticizers, which names and structures are presented in Table 1. The data on ecotoxicological properties of known plasticizers were taken from ECHA website [25]. The following properties were compared: toxicity to fish ( $\left.\mathrm{LC}_{50} / 96 \mathrm{~h}\right)$, toxicity to Daphnia $\left(\mathrm{EC}_{50} / 48 \mathrm{~h}\right)$, toxicity to algae $\left(\mathrm{EC}_{50} / 72 \mathrm{~h}\right)$ and biodegradability after 28 days of the experiment.

Compounds: ASE, GTA and TXIB are not biodegradable, as their biodegradation after 28 days of the experiment was $24 \%, 59.4 \%, 32 \%$, respectively, i.e. below the required $60 \%$. DEHA plasticizer is biodegradable and shows no negative impact on rainbow trout and algae.

However, Daphnia acute toxicity test gave $\mathrm{EC}_{50} / 48 \mathrm{~h}$ equal to $0.66 \mathrm{mg} / \mathrm{dm}^{3}$, which means that DEHA is highly toxic to aquatic organisms and may cause long-term adverse effects in the aquatic environment.

While, DEHT plasticizer is biodegradable and shows no negative impact on rainbow trout and Daphnia. However, algae acute toxicity test gave $\mathrm{EC}_{50} / 72 \mathrm{~h}$ equal to $0.86 \mathrm{mg} / \mathrm{dm}^{3}$, which means that DEHT is highly toxic to aquatic organisms and may cause long-term adverse effects in the aquatic environment.

DBD, DOS and TOTM plasticizers are biodegradable and safe to the aquatic environment, as all the results of ecotoxicological tests presented in Table 4 are below the minimum allowable values.

Whereas, hydroxyester HE-1 is biodegradable, has no negative effect on Daphnia and algae growth rate. However, for algae biomass growth and toxicity to rainbow trout, hydroxyester HE-1 may have harmful effect to aquatic organisms, but only at high concentrations.

\section{Conclusions}

The paper presents results of ecotoxicological tests, including four selected examples: acute toxicity test for rainbow trout, algae growth inhibition test, acute immobilization test for Daphnia, as well as ready biodegradability test.

In case of testing the effect of hydroxyester HE1 on algae growth rate inhibition, $\mathrm{E}_{\mathrm{r}} \mathrm{C}_{50} / 72 \mathrm{~h}$ was above $80 \mathrm{mg} / \mathrm{dm}^{3}$, i.e. the highest used in the experiment, which means that the tested material does not affect algae growth rate. On the other hand, it was found that hydroxyester HE-1 may have negative effect on algae biomass growth, as $\mathrm{E}_{\mathrm{y}} \mathrm{C}_{50} / 72 \mathrm{~h}$ was $48.10 \mathrm{mg} / \mathrm{dm}^{3}$. The obtained test results led to the conclusion that hydroxyester HE-1 can affect the aquatic environment, but only at its highest concentrations.

In case of Daphnia acute immobilization test, $\mathrm{EC}_{50} / 48 \mathrm{~h}$ was above $100 \mathrm{mg} / \mathrm{dm}^{3}$, which, according to [26], means that hydroxyester HE-1 has no negative impact on Daphnia.

In case of acute toxicity test for rainbow trout, $\mathrm{LC}_{50}$ after $96 \mathrm{~h}$ of exposure was $41 \mathrm{mg} / \mathrm{dm}^{3}$, which, according to [26], means that hydroxyester HE-1 can affect the aquatic environment, but only at its highest concentrations.

In turn, in ready biodegradability test, $\%$ of biodegradation of hydroxyester HE-1 after 28 days of experiment was $61.9 \%$, which means it is biodegradable, thus safe to the environment.

Comparison or ecotoxicological results for hydroxyester HE-1 and other commercially available plasticizers leads to the conclusion that hydroxyester HE-1 is an environmentally friendly alternative to these plasticizers that are volatile organic compounds or are harmful to the environment.

Based on the presented results and according to the Appendix to the Regulation of the Minister of Health on criteria and classification methods concerning chemical substances and their mixtures 
[26], it may be concluded that the tested substance - hydroxyester HE-1 is a safe substance and poses no threat to the environment.

This research work was financed as a $R \& D$ project of Inicjatywa Technologiczna I No. 13856, support was granted in the years 2007-2010.

\section{References}

1. P. Ventrice, D. Ventrice, E. Russoa, G. De Sarro, Environ. Toxicol. Pharmacol. 36, 88 (2013)

2. Directive 2004/42/CE of the European Parliament and of the Council (2004).

3. Council Directive 1999/13/EC (1999)

4. T.E. Burghardt, A. Pashkevich, L. Żakowska, Transport. Res Procedia. 14, 714 (2016)

5. Toxicity review for diisobutyl phthalate. U.S. Consumer Product Safety Commission (2011)

6. Ch.A. Staples, D.R. Peterson, T.F. Parkeron, W.J. Adams, Chemosphere 35, 667 (1997)

7. J.V. Barbosa, F. Oliveira, J. Moniz, F.D. Magalhães, M.M.S.M. Bastos, J. Am. Oil. Chem. Soc. 89, 2215 (2012)

8. J.V. Barbosa, E. Veludob, J. Monizc, A. Mendesa, F.D. Magalhăesa, M.M.S.M. Bastosa, Prog. Org. Coat. 76, 1692 (2013)

9. E.S. Beach, B.R. Weeks, R. Stern, P.T. Anastas, Pure Appl. Chem. 85, 1611 (2013)

10. T.T. Bui, G. Giovanoulis, A.P. Cousins, J. Magnér, I.T. Cousins, C.A. deWit, Sci. Total Environ. 541, 451 (2016)

11. A. Schwieck, M.-C. Bock, Build. Environ. 85, $243(2015)$

12. Wypych, G. Handbook of Plasticizers, 2nd ed. (ChemTec Publishing, Toronto 2012)

13. W.J. Tic, W.J., Przem. Chem. 84, 32 (2005)

14. W.J. Tic, J. Guziałowska-Tic, J., Proceedings of the 2nd South East European Conference on Sustainable Development of Energy, Water and Environment Systems, SDEWES.SEE2016. 0038, 1-12 (2016)

15. W.J. Tic, J. Guziałowska-Tic, E. Sutor, W. Butor, Patent EP 2436667 A1 (2012)

16. Regulation (EC) No. 1907/2006 of the European Parliament and of the Council (2006)

17. OECD Guideline for Testing of Chemicals No 201 (2011)

18. OECD Guideline for the Testing of Chemicals No. 202 (2004)

19. OECD Guideline for the Testing of Chemicals No. 203 (1992)

20. OECD Guideline for the Testing of Chemicals No. 207 (1984)

21. OECD Guideline for the Testing of Chemicals No. 209 (2010)

22. OECD Guideline for the Testing of Chemicals No. 216 (2000)
23. OECD Guideline for the Testing of Chemicals No. 217 (2000)

24. OECD Guideline for the Testing of Chemicals No. 301D (1992)

25. ECHA, 2017.

http://echa.europa.eu/information-on-chemicals

26. Regulation of the Minister of Health. Journal of Laws 2012, item 1018 (2012)

27. J. Guziałowska-Tic, W.J. Tic, Pol. J. Environ. Stud. 25, 1515 (2016) 